Julian Bion

Elie Azoulay

\section{The ethics of migration and critical illness}

Received: 6 November 2015

Accepted: 6 November 2015

Published online: 24 November 2015

(C) Springer-Verlag Berlin Heidelberg and ESICM 2015

\section{J. Bion (®)}

Department of Anaesthesia and Intensive Care Medicine, School of Clinical and Experimental Medicine, University of Birmingham, Queen Elizabeth Hospital, Birmingham, UK

e-mail: j.f.bion@bham.ac.uk

\section{E. Azoulay}

Medical Intensive Care Unit, AP-HP, Saint-Louis Hospital ECSTRA team, Biostatistics and Clinical Epidemiology, UMR 1153 (Center of Epidemiology and Biostatistic Sorbonne Paris Cité, CRESS), INSERM, Paris Diderot Sorbonne University, Paris, France

The image of a drowned child in the sands of Bodrum excites our compassion in a manner that statistics cannot. This is no longer a distant refugee crisis, it is Aylan Kurdi: in a different world he might have been playing with our own children on that beach. As physicians we try to make sense of death from disease, to find causal pathways which help us interpret tragic outcomes, live with loss, and prevent others from following the same route. The death of Aylan Kurdi and many more refugees, both children and adults, demands a political version of the causal pathway which understands how desperation and desire drive people to risk their lives in search of sanctuary or affluence, as might we if our positions were reversed. The history of mankind is the history of migration.

The death of a child emphasises our common humanity, but data forces us to consider context and consequences. Official and non-governmental statistics vary widely, but there are estimated to be more than 4 million refugees in camps in the Middle East [8],
1.6 million in Pakistan [3], more than 600,000 applications for asylum in the EU in 2014 [3], more than 600,000 migrants entering the EU this year, and more than 3000 deaths of those attempting to do so via the Mediterranean [5]. And this is just the consequence of war, poor governance, and poverty: if global warming were to make parts of the world uninhabitable, these figures will be several orders of magnitude greater [4]. This is not a problem which is likely to diminish with time, and it is not one we can ignore.

Deprived of adequate social services and healthcare in their countries of origin, and susceptible to acute and critical illness en route, migrants will place additional demands on host societies for access to social benefits, including health and intensive care [7, 6]. However, these societal 'goods' are limited in supply, not least in those countries most susceptible to emigration in which the migrant crisis is an expression of deep social inequalities and historical failure of the principle of justice. While healthcare is not exactly a zero-sum entity, all countries are focused on maximizing efficient use of limited funds, and the needs of migrants will therefore compete with those of the indigenous population for access to medical treatment. There is an extensive literature on rationing intensive care, but these discussions are generally framed in terms of managing competing demand within a system of common entitlement. Migrants challenge that concept: they are 'outsiders', at least from the perspective of the nation state, both culturally and because they may not yet contribute to gross national incomes. To what extent should they be permitted access to the scarce and expensive resource of intensive care?

Basic human rights include the principle of equal moral worth, which means that refugees cannot be refused sanctuary and must therefore be permitted freedom of movement across borders. Residency and societal contribution then earns the right to citizenship and access to the benefits of social membership [1], which includes 
healthcare. The United Nations Convention [9] distinguishes refugees from migrants in general on the basis that the safety of the former is compromised by lack of protection in their own countries, whereas the latter are not persecuted and will continue to receive protection from their governments even when abroad. Refugees, unlike those migrating for work or education, are entitled to protection by the host country and to "the same treatment as is accorded to nationals..." in respect of social security and access to work (Article 24). Social security, however, does not explicitly include healthcare (other than injury), on which subject the Convention remains silent. Article 20 refers to rationing and states that "Where a rationing system exists, which applies to the population at large and regulates the general distribution of products in short supply, refugees shall be accorded the same treatment as nationals". Written shortly after the Second World War, another theatre of human migratory sadness, this article clearly had food and other essentials in mind. However, it could equally well apply to healthcare and intensive care- 'products in short supply'. As the principle of equity of access extends to other parts of the Convention, it seems unlikely that host countries can deny refugees the same level (and same limits) of healthcare as the indigenous population.

While admirable as a statement of principle, there are several problems with practical application of the Convention. The first is that it is not always easy to differentiate refugees from 'economic' migrants when both may come from countries with failed systems of governance and public protection as well as public finances. The second is one of numbers: the impact on the host society is greater and the rate of assimilation slower the larger the diaspora, particularly if immigrants do not share, or have not yet acquired, the same cultural heritage and values as the host nation [2]. The third is that governments, although benevolent by principle, do not have a common approach to accepting refugees or a meaningful metric to determine allocation (e.g. population density rather than population alone). The European response to the human tragedy evolving in Syria and other Middle Eastern states has ranged from the German Chancellor's offer to accommodate 800,000 refugees to the Hungarian Prime Minister's desire to exclude on the basis of religion. This is not just a European phenomenon: even the USA with its long tradition of welcoming migrants has now tightened its border controls, with Emma Lazarus' 'huddled masses' restrained on the other side of the Mexican-Texas fence. Fear and lack of comprehension replace benevolence and non-maleficence both at individual and national level. The net result is that countries closest to the supply of refugees and migrants have had to shoulder the greatest burden even though they may not be the target destination, with consequent impact on their health systems and local populations.

Given the lack of a coherent international strategy for managing mass migration, can intensive care specialists determine access to intensive care in favour of the indigenous population? The answer must be an emphatic 'no'. Intensivists are empowered through training and practice to determine whether a particular patient can benefit from intensive care, and this may include social considerations, but society does not delegate to intensivists the authority to determine moral entitlement, whether on the basis of nationality, religion, ethnicity, or perceptions of worth. The challenge for us as physicians is to make the best use of a scarce resource, including the development of surge capacity; the challenge for politicians is to improve international governance and leadership, overpopulation, and world poverty. If they fail, then we may all become migrants.

\section{Compliance with ethical standards}

Conflicts of interest No conflict of interest.

\section{References}

1. Carens JH (2014) An overview of the ethics of immigration. Crit Rev Int Soc Political Philos 17(5):538-559

2. Collier P (2013) Exodus: immigration and multiculturalism in the 21 st century. Allen Lane, London

3. Eurostat (2015) Asylum statistics. $\mathrm{http}: / /$ ec.europa.eu/eurostat/statisticsexplained/index.php/Asylum_statistics. Accessed 6 Nov 2015

4. IPCC (2014) Climate change 2014: synthesis report. http://www.ipcc.ch/report/ar5/syr/. Accessed 6 Nov 2015
5. Missing Migrants Project (2015) http://missingmigrants.iom.int/. Accessed 6 Nov 2015

6. Poulakou G, Bassetti M, Timsit J-F (2015) Critically ill migrants with infection: diagnostic considerations for intensive care physicians in Europe. Intensive Care Med. doi: 10.1007/s00134-015-4090-9

7. Tsiodras S (2015) Irregular migrants: a critical care or a public health emergency. Intensive Care Med. doi: 10.1007/s00134-015-4088-3
8. United National Humanitarian Commission on Refugees (2015) 2015 UNHCR regional operations profileMiddle East and North Africa (MENA). http://www.unhcr.org/pages/ 4a02db416.html. Accessed 6 Nov 2015

9. United Nations (1951) The 1951 convention and protocol relating to the status of refugees.

http://www.unhcr.org/protect/ PROTECTION/3b66c2aa10.pdf. Accessed 6 Nov 2015 